Foreword

\title{
Ethnographies of Economy/ics: \\ Making and Reading
}

Eugênia Motta; Federico Neiburg; Fernando Rabossi; and Lúcia Müller

In Latin languages, the words economy and economics are one and the same, as in the Portuguese economia. The composite economy/ics reflects an approach that takes economic practices, institutions and social spaces (the economy) and theoretical ideas about the economy (economics) to be interrelated and mutually constitutive spheres, rather than discrete epistemological or ontological entities. One of the objectives of this issue of Vibrant is to propose anthropological research into the multiple forms produced by the entanglement of these two terms. In this approach, academic economic ideas - those produced by professionals of the economy, such as academic economists, economic journalists, market consultants and marketers shape and are shaped by ordinary economic ideas and practices, or in other words, by the economic cultures of non-specialists. Economics thus indicates a field that extends beyond the economic sciences: indeed when we focus on the latter, it is in order to observe how they function as dispositifs (of knowledge and control, we could say, following Foucault). Dispositifs that, at one and the same time, shape and are embedded in what the sciences and economic experts treat as external to themselves: the economy. ${ }^{1}$

\footnotetext{
$1 \quad$ Michel Callon (1998) has highlighted the interest of interrogating the relations between economics and economy as a way of comprehending the mechanisms through which science (economics) performs its objects. However, it is worth recalling that the question of the complex multidimensional and historical relations between economic theories - ideologies in the sense of Hirschman (1977) or Dumont (1979), or cosmologies in the sense of Sahlins (1996) - and the 'reality' of modern capitalism, not as a uniform ontological order but as a space of diversities, was already found at the origin of the discussions concerning the nature of modernity: principally in the German social sciences of the end of the nineteenth century and especially, albeit each in a markedly different form, in authors like Gustav Schmoller, Max Weber and Georg Simmel. For a critique of the reduction of the question of the relations between economics and economy to the problematic of performativity, see Neiburg 2006.
} 
But while in this sense the anthropology of the sciences (of the economic sciences) compels us to speak of the economy, our approach is also constructed through an inverse movement: from the economy to economics. Maintaining the original sense of the term (linked to administration of the house), we observe how the economy extends to other socio-spatial categories: the economy of a nation or a region, the economy of a social class or a class of persons. In all cases, aggregates of persons and things constructed through different principles (geographic, national, social) but always represented by numbers and in some way associated with money, as is the case of the indexes (of equality, poverty, employment, income, indebtedness, GDP, inflation or trust, for example) produced by statisticians, macroeconomists and so many other experts (like administrators, accountants, sociologists, demographers, etc.). ${ }^{2}$

The second objective of this issue of Vibrant is also indicated in the title, in the plural term ethnographies. We are not interested here in any theoretical definition (either a priori or a posteriori) of what economy/ics is (a set of institutionalized processes or an aspect of all human behaviour, for example). ${ }^{3}$ On the contrary, our proposal is a radically ethnographic approach, interested in researching the native meanings of economy/ics, in understanding the uses and meanings of the categories that serve to think and act in the economic universe, or to act and think 'economically' in human relations. ${ }^{4}$ Nor is there here an overall framework or theoretical model through which empirical studies are applied, but ethnographies that deal with actions and ideas, concepts, values and emotions, individual and collective agencies, which provoke theoretical questions through their singularity and historicity. ${ }^{5}$

\footnotetext{
A reverse proposal, which creatively explores the interrelation between folk practices and economic knowledge, was elaborated by Stephen Gudeman and Alberto Rivera (Gudeman \& Riveira 1990).

2 This is an approach that requires us to problematize the anthropological notion of 'house' itself (along with the categories more widely present in economic anthropology, such as domestic group or household) by 'ethnographizing' the links between the space of the family and domesticity and the economy as a government dispositif, or an 'effect of state,' to use Timothy Mitchell's term (1999). Also see Gudeman (2001), Gregory (2009); on numbers, see Porter (1995), Hibou and Samuel (2011) and Neiburg (2010).

3 In the 1960s so-called 'economic anthropology' was obsessively concerned, at least from our contemporary perspective, with defining the economic domain of social life, oscillating between two possibilities: either a set of collective institutions linked to the "production, circulation and consumption of goods," or the 'maximizing' aspect of human actions, as the subdiscipline's 'substantivist' and 'formalist' currents respectively proposed.

4 For an argument along these lines, see Neiburg 2011.

5 In line with this approach, also see the relation established by de l'Estoile (2014) between 'the Economy,' 'living' and 'living well.'
} 
Though not intended to be in any way representative of the discipline's contemporary output, ${ }^{6}$ the set of articles making up this dossier provide a good illustration of the subjects and perspectives that have captured the interest of anthropologists of the economy in recent years: concepts and practices referring to the economy of the house, linked to the anthropology of the family and relatedness (Motta); the boundaries between legal and illegal economies, along with the practices and regulations involved in street markets in a contemporary megalopolis (Hirata); policies designed to improve the economic situation of the poor (Eger and Damo) or the spread of financial pedagogies and practices (Muller); personal and institutional assemblages aimed at producing 'better' performing markets (Onto); personal and collective feelings and passions, such as those linked to the peak and decline of times and places, the gold rush and death of cities (Guedes), or those observed in the poetic universe linked to the joy of being together (Silva). Persons and objects, processes and situations, temporalities and spaces, articulated in thick descriptions that speak about differentiated monies, entangled motivations, different agents and agencies, scales and durations.

The interest in economy/ics accompanied the birth of the social sciences and the discussions concerning the nature of capitalism, the singularities of modern rationality, quantitative forms of relating persons and things, the generalization of the use of money in exchanges, and the existence of specifically 'economic' domains and knowledge. It is this context that explains the meaning of the discussions about the nature of the 'primitive economies' that so enraptured anthropologists at the turn of the twentieth century, ${ }^{7}$ the midcentury concerns with 'peasant' economies or 'informal' economies ${ }^{8}$ or, soon after, the discussions linked to 'development' and 'modernization,' and the 'contact' or 'interaction' between populations and the regime of exchanges

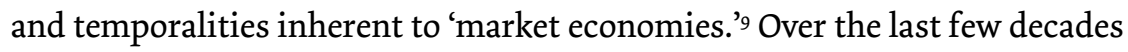

\footnotetext{
6 We have presented the state of the art of the anthropology of the economy in Brazil In other texts: Müller 2010 and Neiburg 2011. Also see Maurer 2013.

7 On the constitutive relations between the concepts of Primitive Man and Homo Economicus, see "Minisymposium: Homo Economicus," published by the Journal of Economic History (2000, 32/4), especially Pearson's article and the responses from various anthropologists, as Keith Hart, Jane Guyer, Bill Maurer, Chris Gregory and James Ferguson.

$8 \quad$ Mintz and Wolf (1957); Hart (1973). For a radically ethnographic perspective of the 'informal economy' in line with the argument in this presentation, see Rabossi 2006.

9 Bourdieu (1977), Geertz (1963), Bloch and Parry (1989).
} 
the renewed interest of anthropologists in economy/ics also provides a lesson relating to the discipline's history: ignoring divisions of labour (such as the one suggesting that economists should be concerned with modern economies and anthropologists with the 'other' economies or the economies of the 'margins') and critiquing and incorporating on the horizon of ethnography itself the cosmology of the Great Divide sustaining these divisions. ${ }^{10}$

The authors of this dossier, based at Brazilian universities, study situations and processes occurring in Brazil. While this does not express the internationalization currently dynamizing the anthropological research conducted in Brazil (including in the anthropology of the economy, where more and more ethnographies are undertaken in regions located outside the country), this concentration on Brazil does allow the dossier to be read too as a set of portraits of the processes transforming contemporary Brazilian society: the subjective experience of economic cycles (Guedes), the modulation of singular forms of sociability (Silva, Motta, Guedes), the dynamics of urban low-income economies (Motta, Muller, Eger and Damo, Hirata), government control of markets (Onto, Hirata), the expansion of social inclusion policies that double as macroeconomic management policies, such as the family allowance (Bolsa Familia, Eger and Damo) or the national financial inclusion policy (Muller).

Had this dossier been written in the United States or Europe, perhaps the global economic crisis would have a more central place in the texts that follow. As well as reflecting the peculiarity of the Brazilian setting - in tune with what we could describe as a post-neoliberal neo-Keynesianism - this comprises an underlying and structuring condition of the analyzed universes. But far from imagining stable and predictable temporalities or social configurations, the texts depict the tensions and conflicts, virtualities and developments defining the contemporary world. It is these old and new tensions that emerge in the articles presented here. Other tensions and other transformations are illuminated by the fine-grained ethnography of the growth of fairs in Pernambuco, presented in the previously unpublished article, written in 1971, by Moacir Palmeira, included in the section Déjà vu.

As we know, the term ethnography has two meanings. It describes a research technique that is simultaneously a personal experience lived in the

10 As examples we can cite the critical reading by Guyer (2004) of Paul Bohanan's idea of spheres of exchange, Zelizer's critique (1998) of Karl Polanyi's differentiation of currencies of specific use from those of multiple use, and Dufy and Weber's formulations (2007). 
interaction with other people over lengthy periods, especially in the field, and also sometimes through written or digital sources. And it also describes the product of the work of ethnographers, presented, generally speaking, in the form of written texts. The articles collected in this dossier are ethnographies in the double sense of the term. This introduction is first and foremost an invitation to read them.

\section{Bibliography}

BLOCH, Maurice and PARRY (orgs.). 1989. Money and the morality of exchange. Cambridge: Cambridge University Press.

BOURDIEU, Pierre. 1977. Algérie 6o. Structures économiques et structures temporelles. Paris, Minuit.

CALLON, Michel. 1998. "Introduction: The embeddedness of economic markets in economics". "In M. Callon (org.), The laws of the markets. Oxford: Blackwell Publishers, pp. 1-57.

De L'ESTOILE, Benoit. 2014. “'Money Is Good, but a Friend Is Better' Uncertainty, Orientation to the Future, and 'the Economy'”. Current Anthropology Volume 55, Number 4.

DUFY, Caroline and WEBER, Florence. 2007. L'ethnographie économique. Paris:

La Découverte.

DUMONT, Louis. 1977. Homo Aequalis: genèse et épanouissement de l'idéologie économique. Paris: Gallimard.

GEERTZ, Clifford. 1963. Peddlers and Princes: social Change and economic

Modernization in Two Indonesian Towns. Chicago and London: The

University of Chicago Press.

GUDEMAN, Stephen. 2001. The Anthropology of Economy. London, Blackwell Publishers.

GUDEMAN, Stephen e Alberto RIVERA. 1990. Conversations in Colombia: The Domestic Economy in Life and Text. Cambridge: Cambridge University Press. GREGORY, Cgris. 2009. "Whatever happened to householding”. In K. Hart, and Ch. Hann, Market and Society. The Great Transformation Today.

Cambridge: Cabridge University Press, pp. 133-159.

GUYER, Jane. 2004. Marginal Gains. Monetary Transactions in Atlantic Africa. University of Chicago Press.

HART, Keith. 1973. "Informal Income Opportunities and Urban Employment 
in Ganha." Journal of Modern African Studies 11(1): 61-89.

HIBOU, Beatrice and SAMUEL, Boris. 2011. "La macroéconomie par le bas". Special Issue: Politique africaine $\mathrm{N}^{\circ} 124 / 4$.

HIRSCHMAN, Albert. 1977. The Passions and the Interests. Political Arguments For Capitalism Before Its Triumph. Princeton University Press.

MAURER, Bill. 2013. "Economy”. In J. Carrier and D. Gewertz (org.). The Handbook of Sociocultural Anthropology. London: Bloomsbury.

MINTZ, Sidney and Eric Wolf. 1957. "Haciendas and plantations in Middle America and the Antilles", Social and Economic Studies, 6: 380-412.

MITCHELL, Timothy. 1999. "Society, Economy, and the State Effect." In G. Steinmetz (ed.), State Formation After the Cultural Turn. Ithaca \& London: Cornell University Press. Pp. 76-97.

MÜLLER, Lúcia Helena. 2010. "A antropologia das instituições e organizações econômicas". In: H. Santos. (Org.). Debates pertinentes: para entender a sociedade contemporânea. Porto Alegre: EDIPUCRS, 2010, v. 1, pp. 139-156.

NEIBURG, Federico. 2006. "Inflation. Economists and Economic Cultures in Brazil and Argentina". Comparative Studies in Society and History (46) 3: 604-633.

NEIBURG, Federico, 2010. "Sick Currencies and Public Numbers". Anthropological Theory, 10 (1/2): 96-102.

NEIBURG, Federico, 2011. "Os sentidos sociais da economia", in L.F. Dias Duarte,. e B. Martin, Antropologia. Horizontes das Ciências Sociais no Brasil, Anpocs / Ciência Hoje / Discurso Editorial / Barcarolla, São Paulo, pp. 225-258.

PEARSON, Heath. 2000. "Economics goes native: 1859-1945. The Rise and Fall of Primitive Economics". History of Political Economy, 32 (4): 932-89.

PORTER, Theodeore. 1995. Trust in numbers. The search for objectivity in science and public life. Princeton,:Princeton University Press.

RABOSSI, Fernando. 2006. Os caminhos da informalidade. Mimeo.

SAHLINS, Marshall. 1996. "The Sadness of Sweetness: The Native Anthropology of Western Cosmology”. Current Anthropology 37 (3): 395-428.

ZELIZER, Viviana. 1994. The social meaning of money. Pin money, paychecks, poor relief and other currencies. 